\title{
Digital Marketing as a Promotional Tourism Strategy in Ecuador. A Systematic Mapping
}

\author{
Alejandra Vera González \\ Universidad Autónoma de San Luis Potosí. \\ Av. Pintores s/n, Col. Burócratas del Estado, \\ San Luis Potosí, S.L.P. México. \\ Invited Senior Researcher at Universidad Tecnológica Equinoccial. \\ Rumipamba s/n y Bourgeois, Zip Code 170147, Quito, Ecuador. \\ Juan Carlos Ortíz Navarro \\ Invited Junior Researcher at Universidad Tecnológica Equinoccial. \\ Rumipamba s/n y Bourgeois, Zip Code 170147, Quito, Ecuador. \\ Andrés Mauricio Mantilla Fuentes \\ Guido Marcelo Salazar Lozada \\ Olivia del Pilar Espinosa Ochoa \\ Universidad Tecnológica Equinoccial. \\ Rumipamba s/n and Bourgeois, Zip Code 170147, Quito, Ecuador.
}

\begin{abstract}
Summary
Digital marketing is a tool that allows the tourism sector to be in the public eyeat an international level. It is part of a strategy of visual and interactive promotion worldwide, which is possible through the use of metadata, web pages and social networks. This investigation demonstrates how relevant digital marketing is in the in the industry of hospitality in Ecuador, through the participation of the Ministry of Tourism, as well as the travel agencies, the tourism promotional agencies and other private sector agents. Systematic mapping was used to identify the contribution of the most widely used digital tools that support the strategies of digital marketing, integrated to the promotion of tourism in Ecuador. Likewise, the main opportunities of the strategic alliance digital marketing - tourism were identified with the intention of boosting the available tools for a growing tourism market.
\end{abstract}

Keywords: digital marketing, tourism, touristic promotion, Ecuador.

\section{Introduction.}

This study presents a revision of what has been published, up to the moment, about the use of digital marketing in the touristic promotion of Ecuador. It allows to identify the strategies that were used to promote touristic centers in other countries and, use them as reference in the analysis of their feasibility in Ecuador.

The main purpose is to determine if the digital marketing utilization as a tool, helps the Ecuadorian touristic sector to develop in an adequate fashion. Some factors have been identified which influence the touristic marketing, but also, the main actors who generate its development and, the marketing models that apply in Ecuador.

This investigation was based on bibliographical analysis, by means of Systematic Mapping, which make it possible to order publications related with the subject, on the basis of the following research questions: Which factors from the touristic sector impact on the promotion of Ecuador through digital marketing?, By means of what digital marketing tools do the touristic operators spread information about destinations in Ecuador?, Which are the digital marketing models currently apply in Ecuador?

Once the information was analyzed, the most relevant findings about the issues in this investigation were defined and highlighted.

\section{Methodology}

The systematic mapping that is used in this work has strengths such as the adequate identification of sources of information through keywords that guide mapping, as well as the amount of information identified and search engines that make it possible to obtain different perspectives from information. 
Among the limitations that it presents, it can be mentioned that, given the vast amount of databases that exist, some relevant articles regarding the subject, can be left out. This methodology is useful for studies of the exploratory type. It defines a process and a report structure in order to categorize the studies that are made up to a moment in a given area; and it is intended for carrying out a thematic analysis on the identification of the main publication forums. (Martínez Y., Cachero C., \& Meliá S., 2011).

Figure 1 shows the systematic mapping process used in this work.

Figure 1: Steps for Systematic Mapping

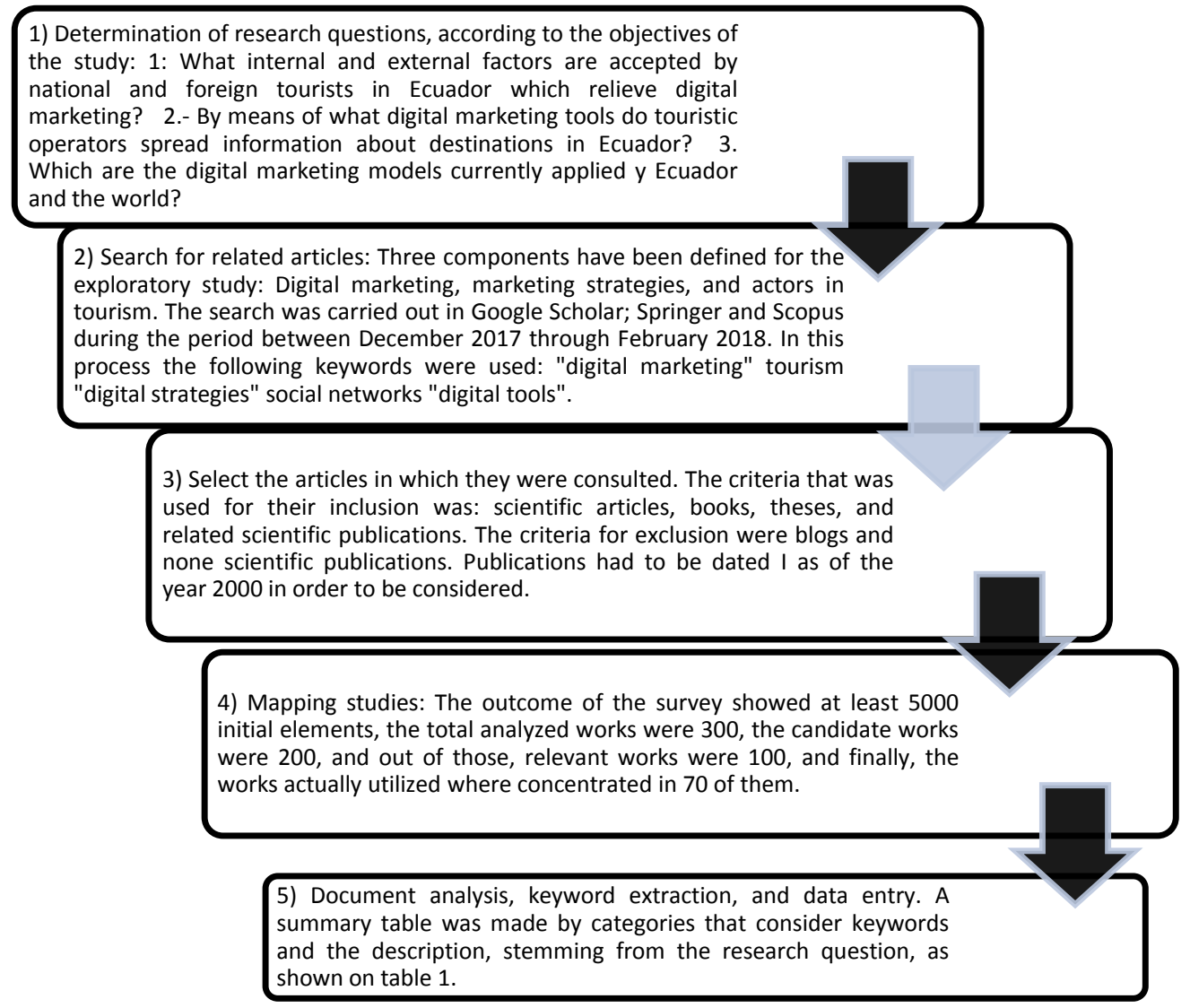

Source: K. Petersen, R. Feldt, S. Mujtaba, and M. Mattsson, "Systematic Mapping Studies in Software engineering," in EASE '08: Proceedings of the $12^{\text {th }}$ International Conference on Evaluation and Assessment in Software Engineering, 2008.

Research questions were integrated and their respective category filters, considering that keywords contribute to the search systematization, as can be observed in Table 1.

Table 1: List of Research Questions related to the category.

\section{Research Question Category (Keywords)}

1. ¿What factors of the touristic Digital marketing, internet, tourism.

sector have an impact on the promotion

of Ecuador through digital marketing?

2.- By means of what digital marketing digital marketing, technology, enterprises, tools do touristic operators spread digital strategies, social networks information about destinations in

Ecuador?

3.- Which are the digital marketing Digital marketing, Ecuador enterprises models currently applied y Ecuador?

Own analysis 
Defined as inclusion criteria were: scientific articles, books, theses, government documents and related publications indexed in the search engines that were used which define and/or mention: "Ecuador", "tourism", "enterprises", "internet", "technology", "digital marketing" "social networks", "digital tools" in any part of the document or metadata (title, abstract, body). The publication period was selected as of the year 2000. From the results of the analyzed databases, the first 50 documents were considered, and out of each one, the summary was reviewed in order to verify its pertinence and contribution to the study's information. Non-scientific opinions and publications were discarded. Table 2 shows the process of search and discrimination of the sources.

Table 2.- Breakdown by search engine

\begin{tabular}{|c|c|c|c|c|c|c|c|c|c|}
\hline & Results of Search & Analyzed & Works & Candidate & Works & Relevant & Works & Utilized & Works \\
\hline Scholar & 5000 & & 3000 & & 200 & & 100 & & 62 \\
\hline Springer & 8341 & & 2032 & & 287 & & 50 & & 5 \\
\hline Scopus & 1492 & & 973 & & 93 & & 66 & & 4 \\
\hline
\end{tabular}

By own compilation

The most utilized search engine is Google Scholar since we found a great amount of articles for the organization of information. Springer and Scopus we're also utilized. For each utilized source, information was compiled referred through the years of publication and keywords. Data was extracted and it is shown in the results section.

\section{Results}

Information obtained and classified helped to determine the variables, by showing the current situation of Tourism and digital marketing in Ecuador, as well as the current demand conditions of the Ecuadorian market. (Ecuadorian Tourism Ministry, 2014).

The integral tourism marketing plan of Ecuador (2014) poses a force analysis of opportunities, weaknesses, and threats to help sustain the purpose of this investigation, some of which are explained below. As strengths we have aerial connectivity direct from the main cities of Quito and Guayaquil with outbound tourism markets like the United States and Colombia; the recognition of Ecuador as a touristic destination among the key touristic actors of the main outbound markets, as well as Ecuador being a country with great landscape diversity and varied resources. Regarding weaknesses, there is no direct air connection with some of the main markets of America and Europe; poor aerial infrastructure, maritime and land transportation are not quite competitive. It also shows little innovation in touristic products. Opportunities exist in adventure and sports tourism as well as community tourism, likewise, in developing cultural tourism on a higher scale, with a sense of "back to the origins". Identified as a possible threat is the tendency to reduce the cost of incentives and corporate reunions on the part of enterprises, which the majority of the outbound markets have shown since they have entered or are about to enter a recession for which touristic forecasts of growth, according to the Tourism World Organization, present stagnation or even descent in the short and medium terms.

In the above-mentioned plan, Ecuador has classified touristic products by promotional typology, this means the designation of different resources to each type of touristic product. The product with the highest priority are the key or star products, so called because of their potential, adequacy, and because they generate the maximum value to the visitor, since they are particularly attractive to the tourist. The second most important priority for the country, belongs to the consolidation products, less attractive than the previous ones and with a lower value contribution than the Star products. The marketing investment is slightly lower to that of key products. Starproducts are cultural tourism, ecotourism, nature tourism and sports and adventure tourism. Consolidation products are community tourism, convention and conferences tourism and cruise tourism. And, opportunity products are sun and beach tourism, health, agro-tourism and theme parks, with a lower investment than the previous ones (Integral Marketing Plan, Ministry of Tourism, 2014).

In Table 3, 71 publications are registered that are relevant to the keywords, number of publications found, the year, and the type of publication. 
Table 3.- Number of publications by keyword, year and type of publication

\begin{tabular}{|c|c|c|c|c|}
\hline KEYWORD & $\begin{array}{l}\text { NUMBER OF } \\
\text { PUBLICATIONS }\end{array}$ & $\begin{array}{c}\text { FREQUENCY } \\
(\%)\end{array}$ & $\begin{array}{c}\text { YEAR OF } \\
\text { PUBLICATION }\end{array}$ & TYPE OF PUBLICATION \\
\hline Enterprises-Ecuador & 1 & \multirow{7}{*}{$9.86 \%$} & 2008 & scientific article \\
\hline Enterprises-Ecuador & 1 & & 2011 & scientific article \\
\hline Enterprises-Ecuador & 1 & & 2012 & scientific article \\
\hline Enterprises-Ecuador & 1 & & 2014 & scientific article \\
\hline Enterprises-Ecuador & 1 & & 2014 & government document \\
\hline Enterprises-Ecuador & 1 & & 2017 & scientific article \\
\hline Enterprises-Ecuador & 1 & & 2018 & government document \\
\hline Internet & 1 & \multirow{6}{*}{$9.86 \%$} & 2001 & scientific article \\
\hline Internet & 1 & & 2002 & scientific article \\
\hline Internet & 1 & & 2011 & Book \\
\hline Internet & 1 & & 2012 & scientific article \\
\hline Internet & 2 & & 2015 & scientific article \\
\hline Internet & 1 & & 2016 & scientific article \\
\hline Digital Marketing & 1 & \multirow{14}{*}{$38.03 \%$} & 2000 & scientific article \\
\hline Digital Marketing & 1 & & 2001 & Book \\
\hline Digital Marketing & 1 & & 2002 & scientific article \\
\hline Digital Marketing & 2 & & 2008 & scientific article \\
\hline Digital Marketing & 2 & & 2009 & scientific article \\
\hline Digital Marketing & 3 & & 2011 & scientific article \\
\hline Digital Marketing & 3 & & 2012 & scientific article \\
\hline Digital Marketing & 2 & & 2013 & scientific article \\
\hline Digital Marketing & 3 & & 2014 & scientific article \\
\hline Digital Marketing & 1 & & 2014 & Book \\
\hline Digital Marketing & 1 & & 2014 & scientific article \\
\hline Digital Marketing & 1 & & 2016 & Book \\
\hline Digital Marketing & 3 & & 2016 & scientific article \\
\hline Digital Marketing & 3 & & 2018 & scientific article \\
\hline Technology & 1 & \multirow{6}{*}{$10 \%$} & 2010 & scientific article \\
\hline Technology & 1 & & 2015 & scientific article \\
\hline Technology & 1 & & 2016 & scientific article \\
\hline Technology & 1 & & 2018 & scientific article \\
\hline Technology & 1 & & s.f. & scientific article \\
\hline Technology & 2 & & 2017 & scientific article \\
\hline Tourism & 1 & \multirow{6}{*}{$32.39 \%$} & 2006 & scientific article \\
\hline Tourism & 1 & & 2007 & professional thesis \\
\hline Tourism & 1 & & 2007 & government document \\
\hline Tourism & 1 & & 2007 & Book \\
\hline Tourism & 1 & & 2009 & government document \\
\hline Tourism & 1 & & 2011 & scientific article \\
\hline
\end{tabular}




\begin{tabular}{|c|c|c|c|c|}
\hline Tourism & 1 & & 2012 & Magazine \\
\hline Tourism & 1 & & 2012 & professional thesis \\
\hline Tourism & 2 & & 2012 & scientific article \\
\hline Tourism & 2 & & 2012 & Magazine \\
\hline Tourism & 1 & & 2013 & scientific article \\
\hline Tourism & 1 & & 2014 & scientific article \\
\hline Tourism & 1 & & 2015 & scientific article \\
\hline Tourism & 1 & & 2016 & professional thesis \\
\hline Tourism & 1 & & 2016 & Book \\
\hline Tourism & 2 & & 2016 & scientific article \\
\hline Tourism & 2 & & 2016 & Magazine \\
\hline Tourism & 1 & & 2018 & scientific article \\
\hline Tourism & 1 & & s.f. & Magazine \\
\hline Total Publicaciones & 71 & $100 \%$ & & \\
\hline
\end{tabular}

Own Analysis

The keyword Digital Marketing encompasses: digital strategies, digital tools, social networks. Regarding the keywords: Technology, Internet, and Enterprises - Ecuador, they are representative because they derive from the research questions and are closely related to the inter-relations that arise from the appearance of each one of them. They contribute from their realm to the process of innovation giving birth to new knowledge and new digital marketing practices in tourism. The term "Internet" filters information and limits the field of search and constitutes the base for the emergence and development of Digital Marketing. The combination of the terms "Tourism" and "Digital Marketing" and "Enterprises-Ecuador", put in context the tracing of specific information of the country and allows us to know the state of the art of this subject matter.

Out of the analyzed publications, the variables are grouped in two dimensions for the construction of the bubble type scatter plot. The classification can be appreciated in Table 4 .

Table 4.- Summary of publications by keyword and type of publication

\begin{tabular}{lrrrrrr}
\hline \multicolumn{1}{c}{ Keywords } & $\begin{array}{c}\text { Scientific } \\
\text { article }\end{array}$ & Book & Thesis & $\begin{array}{c}\text { Government } \\
\text { document }\end{array}$ & Magazines & Total \\
\hline Technology & 7 & 0 & 0 & 0 & 0 & 7 \\
\hline Enterprises-Ecuador & 5 & 0 & 0 & 2 & 0 & 7 \\
\hline Tourism & 10 & 2 & 3 & 2 & 6 & 23 \\
\hline Internet & 6 & 1 & 0 & 0 & 0 & 7 \\
\hline Digital marketing & 24 & 3 & 0 & 0 & 0 & 27 \\
\hline
\end{tabular}

Own Analysis

The majority of the analyzed articles are concentrated in studies related to digital marketing and tourism, as well as some theses, magazines and government documents. (Figure 2). Taking the research questions as a guide and analyzing the information, 20 publications have been found that refer to the factors or elements that determine the development of the touristic promotion through digital marketing shown in table 5. 
Figure 2: Distribution of publications by keywords and type of publication

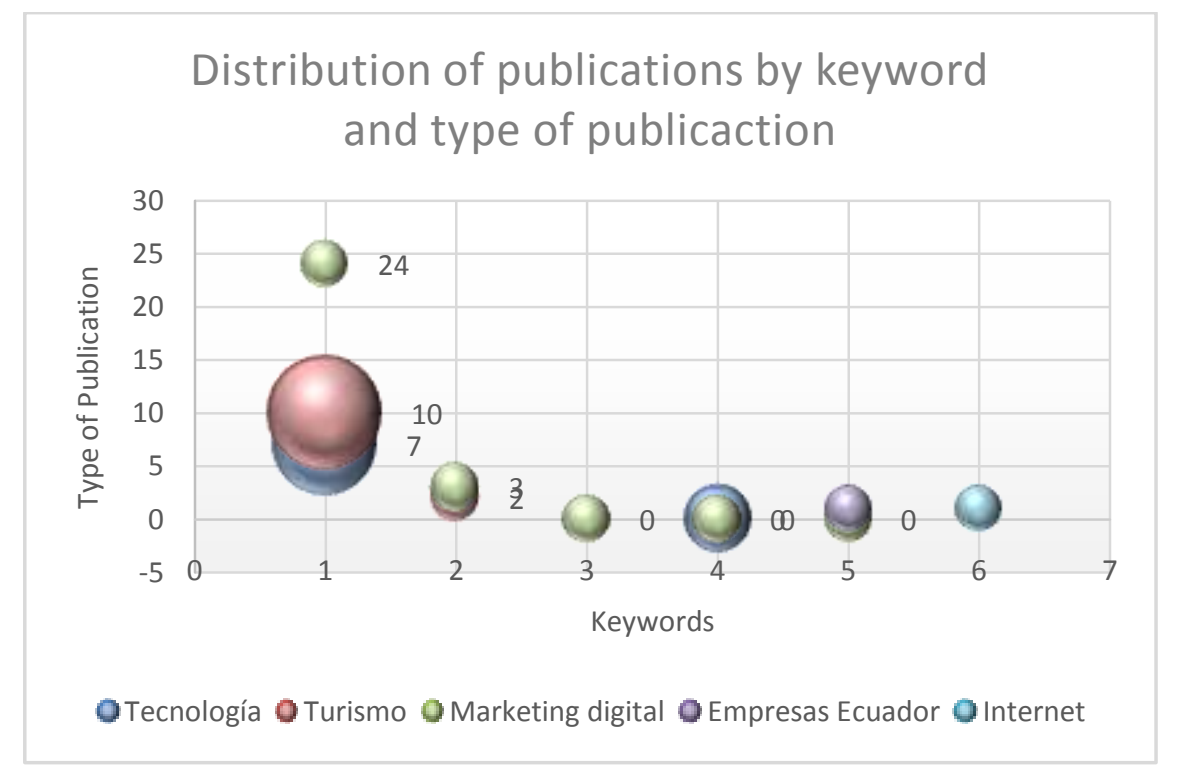

By own analysis

Table 5.- Factors associated to the first and second questions of the problem

1. What factors of the touristic sector influence the promotion of Ecuador through digital marketing?

\begin{tabular}{|c|c|c|}
\hline $\mathbf{N}^{\mathbf{0}}$ & Factors & Reference \\
\hline 1 & Separation of marketing thinking from economic thinking & $\begin{array}{l}\text { (García, 2010). } \\
\text { (Pesonen, 2012). }\end{array}$ \\
\hline 2 & $\begin{array}{l}\text { Marketing and the media are considered as sources of } \\
\text { development for the hospitality industry. }\end{array}$ & $\begin{array}{l}\text { (Miranda, Rubio, Chamorro, \& } \\
\text { Correia, } \\
\text { (Laso, I.\& Iglesias, M., 2015). } \\
\text { (Galiana, P. 2016). }\end{array}$ \\
\hline 3 & $\begin{array}{l}\text { Internet as media outlets towards the tourist and trip } \\
\text { planning }\end{array}$ & $\begin{array}{l}\text { (Beltrán, 2016). } \\
\text { (Anato, 2006) } \\
\text { (Briz J.\& Laso I., 2001) } \\
\text { (Doolin et al., 2002) } \\
\text { (Rita, 2000). } \\
\text { (Díaz-Luque \& Jiménez Marín, } \\
\text { 2013). } \\
\text { (Sellers Rubio, R., Azorín Escolano, } \\
\text { A., 2001) }\end{array}$ \\
\hline 4 & $\begin{array}{l}\text { The customization of products and services on the part of } \\
\text { digital marketing tools }\end{array}$ & (Flores, 2012). \\
\hline 5 & $\begin{array}{l}\text { Banking on studies of the socio-economic and cultural } \\
\text { environment for doing tourism digital marketing. }\end{array}$ & (Torres, 2007). \\
\hline 6 & $\begin{array}{l}\text { Connectivity, sustainability, governance, information } \\
\text { systems and innovation, all try to create intelligent } \\
\text { destinations }\end{array}$ & $\begin{array}{l}\text { (Ivars Baidal, Solsona Monzonís, \& } \\
\text { Giner Sánchez, 2016). }\end{array}$ \\
\hline 7 & $\begin{array}{l}\text { Shopping becomes a decision factor that interacts with } \\
\text { places and anthropology }\end{array}$ & $\begin{array}{l}\text { (Kinley, Forney, \& Kim, 2012). } \\
\text { (Alvear, 2017). }\end{array}$ \\
\hline 8 & $\begin{array}{l}\text { Coordinated work between entities of the public sector that } \\
\text { include the Ministry of Science and Technology }\end{array}$ & (Metodijeski \& Temelkov, 2014) \\
\hline 9 & The evolution of marketing towards the digital era & (IBM,2012) \\
\hline
\end{tabular}


10 Innovating Technics that support digital marketing

Own Analysis

With reference to the second question of the research problem, 31 publications related to factors that define the tools of digital marketing have been found, which are commonly employed by touristic operators for promotion on a global scale as well as in Ecuador (Table 5)

Table 6 depicts those factors that can influence or represent elements of digital marketing models in the country, both, in the public and the private sectors. In total, 20 publications are recorded.

Table 6.- Factors associated to the third question of the problem

\begin{tabular}{|c|c|c|}
\hline \multicolumn{3}{|c|}{$\begin{array}{l}2 .- \text { Through what digital marketing tools do touristic operators spread information about destinations } \\
\text { in Ecuador? }\end{array}$} \\
\hline No & $\begin{array}{ll}\text { Factors } \\
\end{array}$ & References \\
\hline 11 & $\begin{array}{l}\text { Use of devices and mobile advertising as a digital } \\
\text { strategy }\end{array}$ & $\begin{array}{lll}\text { (Andrade, } & & \text { 2016) } \\
\text { (Wang, Xiang, \& Fesenmaier, 2016). } & \text { 2017). } \\
\text { (Gan, } & & \text { 2016) } \\
\text { (Osorio, Restrepo, \& Muñoz, } \\
\text { (Florido, L., Del Alcázar, B., González, E., } \\
\text { 2015) }\end{array}$ \\
\hline 12 & $\begin{array}{l}\text { Use of recommendation systems, social network and } \\
\text { virtual communication management }\end{array}$ & 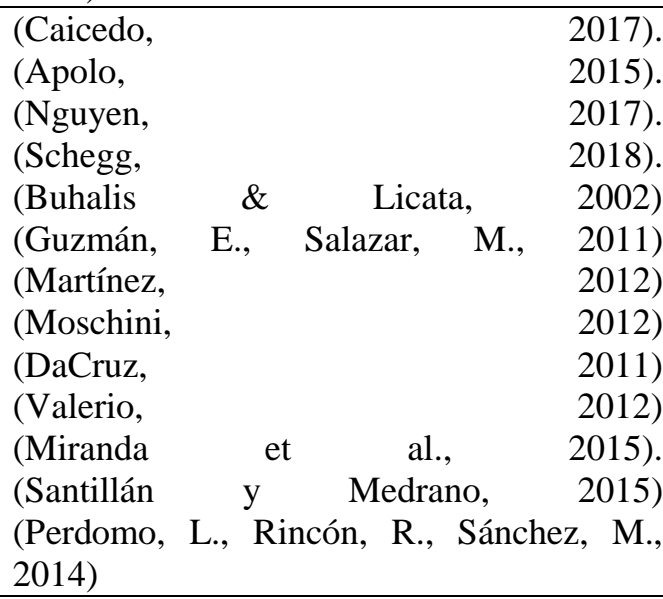 \\
\hline 13 & The use of software for touristic decision making & 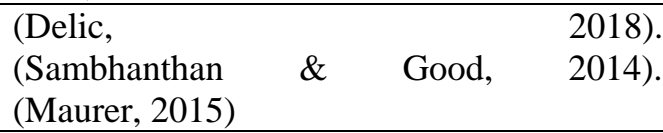 \\
\hline 14 & The web as a tool of efficiency, low cost and loyalty & $\begin{array}{ll}\text { (Espinosa, } & 2015) \text {. } \\
\text { (Matellanes, } & 2012) . \\
\text { (DeCamargo, } & 2008) \\
\text { (Lara, P, Martínez, } & \text { J. } \\
\text { (Selman, D., 2017) }\end{array}$ \\
\hline 15 & $\begin{array}{l}\text { The user as protagonist in the utilization of } \\
\text { technologies } 2.0\end{array}$ & $\begin{array}{l}\text { (Bellón A. \& } \quad \text { García } \\
\text { (Celdrán, M. et al., 2018) }\end{array}$ \\
\hline 16 & The use of tactics and technologies in digital marketing & (Torres 2009, citado por Mendes, 2013). \\
\hline 17 & The use of digital marketing & (Fernández, 2016). \\
\hline
\end{tabular}




\begin{tabular}{|l|l|l|}
\hline \multicolumn{2}{|c|}{ 3.- Which are the digital marketing models that currently apply in Ecuador? } \\
\hline $\mathrm{N}^{\circ}$ & \multicolumn{1}{|c|}{ Factors } & \multicolumn{1}{c|}{ Reference } \\
\hline 18 & & $\begin{array}{l}\text { (Turism\&Leisure, 2009) } \\
\text { (Caiza, 2012) } \\
\text { (García, 2016) } \\
\text { (Ballesteros, E. R., \& Carrion, D. S. , 2007). } \\
\text { (Küster, Vila, \& Canales, 2008). } \\
\text { (Turism\&Leisure,2007) } \\
\text { (TIC Observatorio, 2018). } \\
\text { (Rodríguez, 2017). } \\
\text { (Cabanilla, 2014) }\end{array}$ \\
$\begin{array}{l}\text { Participation of key participants from the public, private sectors } \\
\text { and community in general empowered through direct and } \\
\text { alternative marketing in digital media }\end{array}$ & $\begin{array}{l}\text { Technological innovation for the development of touristic } \\
\text { marketing }\end{array}$ & $\begin{array}{l}\text { (Gretzel, Sigala, Xiang, \& Koo, 2015). } \\
\text { (Martínez, J., 2011) }\end{array}$ \\
\hline 20 & $\begin{array}{l}\text { Inclusive technological touristic programs (handicapped } \\
\text { persons) }\end{array}$ & $\begin{array}{l}\text { (Doolin et al., 2002) } \\
\text { (Bazazo \& Alananzeh, 2016) }\end{array}$ \\
\hline 21 & \multicolumn{2}{|c|}{$\begin{array}{l}\text { (Laudon, 2014) } \\
\text { (Rodríguez, C., 2009) }\end{array}$} \\
\hline 22 & $\begin{array}{l}\text { Permission marketing in e-mail and affiliation marketing. } \\
\text { The use of social media as a tool for the generation of } \\
\text { expectations }\end{array}$ & $\begin{array}{l}\text { (Fredes Lucas F., 2008) } \\
\text { (Kalakota, R.\& Robinson, M., 2001) }\end{array}$ \\
\hline 23 & $\begin{array}{l}\text { (Altamirano, 2014). } \\
\text { (Ministerio de Turismo, 2014) } \\
\text { (Altamirano, V., Marín, I., , Ordoñez, K., } \\
\text { 2018) }\end{array}$ \\
\hline
\end{tabular}

\section{Discussion}

Amongst revised literature, some factors are evident in which various authors coincide regarding the definition of tools that contribute to the touristic promotion in Ecuador. Thus, García (2010) and Personen (2012), mention that its necessary two separate the marketing approach from the economic approach, in the evolution that marketing has experienced up until now, as much as in the change of paradigm that the economic thought has experienced from its beginnings; as well as in the focus that each one of them currently applies in front of the customer as in the business processes inside the organizations.

Media and marketing have become sources of development for the hospitality industry (Lass, I.\&Iglesia, M., 2002), (Galiana, P. 2016), knowing the needs of the customer through interactive communication. Internet simplifies travel planning, purchase and product personalization as well as touristic services through the various digital marketing tools.

Successful promotion of Tourism depends greatly on an adequate study of the surroundings and reality of a country (Torres, 2007), as well as banking on an inventory of attractions, the potential that a territory has, allows for the projection of the most adequate actions, boosting them with the various tools that digital marketing offers, which can be applied through the use of digital marketing plans. (Fernández, 2016). The networks and communities online, group the market in specific segments, thanks to conductivity, sustainability and governance of the information systems (Ivars, 2016), transforming purchasing in the most important decision factor that generates the interaction with touristic places, diversifying the objective of the market, and improving consumption habits. (Kinley, Forney, \& Kim, 2012; Alvear, 2017).

Technologies that promote the growth of digital marketing, such as social networks, offer distinct experiences for the consumer. Gimeno (2016) establishes that evolution is improving the capacity of attracting the desired objective market. Mobile devices have made it possible to carry out strategies of mobile publicity, with fast access two information by the consumer, improving effectiveness in the process of offering touristic products and services. The use of Technology 2.0, the web, planning and recommendation systems, network operators and virtual communities, turn the traditional consumer into a digital consumer, a strategic ally of the touristic sector, promoting the loyalty of the customer (Bellón A. \& García J. 2011), (Celdrán, M. et al., 2018). 
Through digital marketing the user turns into the protagonist in order to facilitate decision making of future clients according to (Delic, 2018), (Sambhanthan \& Good, 2014), (Maurer, 2015), (Espinosa, 2015), (Matellanes, 2012), (DeCamargo, 2008), (Lara, P. Martínez, J. 2002), (Selman, D., 2017), (Bellón A. \& García J. 2011), (Celdrán, M. et al., 2018).

Technological programs for touristic development, increase the capacity of response and generate a growth in demand, including programs for handicapped people, where it can be observed that tourism operators invest efforts and empower these characteristics in order to increase the market. (Doolin et al., 2002), (Bazazo \& Alananzeh, 2006).

In Ecuador, the Ministry of Tourism, through PLANDETUR, seeks to empower the support of embassies and external actors. It also considers that there are private enterprises which are part of the fundamental technological infrastructure for innovating the customer's experience. (Altamirano, 2014), (ministry of Tourism, 2014).

If it is true that digital marketing has globally reached considerable development, in Ecuador touristic communication 2.0 is incipient. The use of social networks is still low in comparison with developed nations. (Altamirano, V., Marín, I., Ordoñez, K., 2018).

\section{Conclusions}

Through research it has been identified that amongst the factors that have a bearing on touristic promotion, the first thing to be considered is a change of thought from the strictly economic, towards a marketing focus, on the part of the actors that participate in the hospitality industry, in the public sector as much as the private sector.

An evolution of Marketing has been observed, through the influence of technology, manifested in this case by the use of internet, which creates new concepts, strategies and tools that bring about Digital Marketing, which in tourism, encourages the active participation of the users. Tools such as social network and virtual communications operators, the use of software for touristic decision making, as well as the use of Technologies to promote touristic products and services.

The hospitality sector of Ecuador uses models created outside of the national territory, due to these and other processes of communication, they have evolved, nevertheless, the touristic promotional platforms are still traditional and one way and oriented.

The digital tools have proved to be a link with the individuals that visit foreign countries, since they allow the optimization of the search time, the money, as part of their investment, and the comfort of the tourist; with the purpose of forming a long-lasting relationship that guarantees his well-being.

It is suggested to investigate the combination of digital marketing and tourism, as a binomial, to promote those places in Ecuador whose characteristics make them important to be visited. Through digital marketing it would be possible to reach more users through tools such as a web page, e-mailing, blogs and social networks, in order to get new customers as well as existing customers.

Personalization of products and services is customized to the needs of each tourist, offering them the possibility to select among various alternatives at the moment of planning their trip.

In Ecuador, social networks and web pages are strategies applied by the Ministry of Tourism, travel agencies and terroristic promoters who have their own digital tools that are used by national and foreign tourists. E-mail in Ecuador is frequently used; which has allowed to maintain a communication Channel with tourists in order to offer them trouble free travel. The ministry of Tourism and the private sector I working close together in order to turn Ecuador into a unique touristic destination, with which it will be possible to create a new model touristic promotion.

\section{References}

Altamirano, V. (Diciembre de 2014). Promoción y Difusión Turística en Iberoamérica. Recuperado de: http://www.revistalatinacs.org/14SLCS/2014_actas/050_Altamirano.pdf

Altamirano, V., Marín, I., Ordóñez. K. (2018). "Comunicación turística 2.0 en Ecuador. Análisis de las empresas públicas y privadas". Revista Latina de Comunicación Social, 73, pp. 633 a 647. Recuperaado de: http://www.revistalatinacs.org/073paper/1273/32es.html DOI: 10.4185/RLCS-2018-1273

Anato, M. (ene-mar de 2006). El uso de los instrumentos clásicos del marketing y la tecnología digital en turismo. Recuperado de www.scielo.org.ar: http://www.scielo.org.ar/scielo.php?script=sci_arttext\&pid=S1851$17322006000100002 \&$ lang $=\mathrm{pt}$

Andrade, D. (2016). Estrategias de marketing digital en la promoción de marcaciudad.Rev.esc.adm.neg.,59-72. Recuperado dehttp://www.redalyc.org:9081/html/206/20645903005/ 
Alvear, Gladys. (2017). CONSUMIDORES TURÍSTICOS DIGITALES UNA ALTERNATIVA PARA LA SOSTENIBILIDAD. Revista Universidad y Sociedad, 9(1), 161-164. Recuperado de http://scielo.sld.cu/scielo.php?script=sci_arttext\&pid=S2218-36202017000100023\&lng=es\&tlng=es

Apolo, D. (2015). Usuarios, clientes y consumidores digitales. Redmarka: revista académica de marketing aplicado, 319. Recuperado de https://dialnet.unirioja.es/ejemplar/402691

Ballesteros, E. R., \& Carrion, D. S. (2007). Turismo comunitario en Ecuador: desarrollo y sostenibilidad social. Editorial Abya $\quad$ Yala. Recuperado de.https://books.google.com.ec/books/about/Turismo_comunitario_en_Ecuador.html?id=7YCV1rBUxx0

Bazazo, I. K., \& Alananzeh, O. A. (2016). The Effect Of Electronic Tourism In Enabling The Disabled Tourists To Communicate With The Touristic And Archaeological Sites Case Study - Jordan, 12(5), 111-129. Recuperado de https://doi.org/10.19044/esj.2016.v12n5p111

Bellón, A. García, J. (2011). Aplicación y uso de la web 2.0 y de las redes sociales en la comunicación científica especializada: del marketing viral al usuario activo. 61-70. Recuperado de https://dialnet.unirioja.es/descarga/articulo/3719137.pdf

Briz J.\& Laso I. (2001). Internet y comercio electrónico. Madrid: Editor Mundi-Prensa, 2da Edición.

Buhalis, D., \& Licata, M. C. (2002). The future eTourism intermediaries. Tourism Management, 23(3), 207-220. Recuperado de https://doi.org/10.1016/S0261-5177(01)00085-1

Cabanilla E. (2014). Desarrollo del turismo comunitario en Ecuador, bajo el paradigma de la complejidad desde la perspectiva local del Sumak Kawsay. Revista BioScriba, 7(1), 30-49. Recuperado de https://s3.amazonaws.com/academia.edu.documents/32165071/Desarrollo_del_turismo_comunitario_global_ perspectiva_local.pdf?AWSAccessKeyId=AKIAIWOWYYGZ2Y53UL3A\&Expires=1530230957\&Signature $=$ L6kDMTEuOSL0\%2BcfNswVFLLVZ3T8\%3D\&response-contentdisposition=inline\%3B\%20filename\%3DDesarrollo_del_turismo_comunitario_en_Ec.pdf

Caicedo, A.V., Melgar, E.G. y Torres, S.J. (2017). International Journal of Scientific Management and Tourism, 2017, Vol. $3 \mathrm{~N}^{\circ} 1$ pp 47-58: DIAGNÓSTICO DE LA FIGURA DEL GESTOR DE REDES SOCIALS COMO APOYO DE EMPRESAS TURÍSICAS EN GUAYAQUIL. Recuperado de https://dialnet.unirioja.es/descarga/articulo/5975079.pdf

Caiza, R. (2012). Análisis Histórico de la evolución del turismo en el territorio ecuatoriano. Universidad de especialidades turísticas-UC, 1-24. Recuperado dehttps://dialnet.unirioja.es/servlet/articulo?codigo=4180961

Celdrán Marco \& José-N Mazón. (2018). SMART TOURISM. A STUD ON SYSTEMATIC MAPPING. Cuadernos de Turismo, $\mathrm{n}^{\mathrm{o}} 41,655-658$.

DaCruz, G. (ene-jun de 2011). Twitter, Youtube e innovación en la promoción turística online. Obtenido de Estudios y perspectivas en turismo: Recuperado de http://www.scielo.org.ar/scielo.php?script=sci_arttext\&pid=S1851$17322011000300006 \&$ lang $=\mathrm{pt}$

DeCamargo, P. (abr-jun de 2008). Análisis de las mejores estrategias de promoción en la web desarrolladas por los destinos turísticos internacionales. Obtenido de EStudios y perspectivas de turismo: Recuperado de http://www.scielo.org.ar/scielo.php?script=sci_arttext\&pid=S1851-17322008000200005\&lang=pt

Delic, A. (2018). An observational user study for group recommender systems in the tourism domain. Inf Technol Tourism. Recuperado dehttps://link.springer.com/article/10.1007/s40558-018-0106-y

Díaz-Luque, P., \& Marín, G. J. (2013). La web como herramienta de comunicación y distribución de destinos turísticos. Análisis y modelos. Questionespublicitarias, 18(1),39-55. Recuperado de https://idus.us.es/xmlui/handle/11441/28981

Doolin, B., Burgess, L., \& Cooper, J. (2002). Evaluating the use of the Web for tourism marketing: a case study from New Zealand. Tourism Management,23,557-561. Recuperado de http://www.academia.edu/7291173/Evaluating_the_use_of_the_Web_for_tourism_marketing_a_case_study_fr om_New_Zealand

Espinosa, V. (2015). Propuesta de plan de marketing digital para el hotel makana resort ubicado en Tonsupa, Esmeraldas, Ecuador. Recuperado de http://dspace.udla.edu.ec/handle/33000/4729

Fernández, P. (2016). Metodología para la elaboración de un plan de marketing online, 5(2006), 57-72. Recuperado de https://www.google.com.mx/search?sourceid=navclient\&aq=\&oq=Metodolog\%c3\%ada+para+la+elaboraci\%c $3 \% \mathrm{~b} 3 \mathrm{n}+\mathrm{de}+$ un+plan+de+marketing+online \&hl=es\&ie=UTF-

8\&rlz=1T4GGHP_esMX470MX470\&q=Metodolog\%c3\%ada+para+la+elaboraci\%c3\%b3n+de+un+plan+de+ marketing+online\&gs_l=hp...0.0.0.15.88657...........0.vto6y_JqrdE

Florido, L., Del Alcázar, B., González, E. (2015),El beneficio de la gestión de relación entre las empresas y turistas a través de las aplicaciones móviles como herramienta de marketing y elemento diferenciador de los destinos turísticos. Universidad de Málaga. España. Vol. 5. Nº 2. Recuperado de: 
http://revistes.ub.edu/index.php/ara/article/view/19065/21543

Flores, P. (2012). Propuesta de modelo digital integral de Marketing Digital Aplicado a las empresas de Turismo en el Distrito Metropolitano de Quito Caso: Metropolitan Touring, 193. Recuperado de http://repositorio.puce.edu.ec/bitstream/handle/22000/5496/T-PUCE-5723.pdf?sequence=1

Fredes Lucas F. (2008). Marketing Digital aplicado al Turismo. Universidad Nacional de Mar del Plata. Recuperado de http://nulan.mdp.edu.ar/1819/1/fredes_lf_2008.pdf

Galiana, P. (2016). 8 Tendencias del Marketing Digital. Marketing Digital: Tendencias, novedades, noticias del mundo del marketing digital. Recuperado de https://www.iebschool.com/blog/tendencias-2016-marketing-digital/

García, C. (2016). TURISMO COMUNITARIO EN ECUADOR: ¿QUO VADIS?. Estudios y Perspectivas en Turismo, 25 (4), 597-614 Recuperado de http://www.redalyc.org/pdf/1807/180747502011.pdf

García, J. (2010) El Marketing y su origen a la orientación social: desde la perspectiva económica a la social. Los aspectos de organización y comunicación. Em Questão [en linea] 2010, 16 (Enero-Junio) : [Fecha de consulta: 21 de marzo de 2018] Recuperado dehttp://www.redalyc.org/articulo.oa?id=465645962005 $>$ ISSN1807-8 F

Gan, E. (2017). Mining graphs from travel blogs: a review in the context of tour planning. Inf Technol Tourism (2017), 17:429-453. Recuperado de https://link.springer.com/article/10.1007\%2Fs40558-017-0095-2

Gimeno, M. (2016). La Transformación Digital en el Sector Turístico. Orange Fundación. Recuperado de http://www.fundacionorange.es/wpcontent/uploads/2016/05/eE_La_transformacion_digital_del_sector_turistico.pdf.

Gretzel, U., Sigala, M., Xiang, Z., \& Koo, C. (2015). Smart tourism: foundations and developments. Electronic Markets, 25(3), 179-188. Recuperado de https://doi.org/10.1007/s12525-015-0196-8

Guzmán,E., Salazar, M. (2011), El marketing turistico en Ecuador, caso visitaecuador.com, Turydes.vol 4, Recuperado de http://www.eumed.net/rev/turydes/10/gbsr.pdf.

International Business Machine. (2012). Big Data \& Analytics aumenta la madurez del marketing digital. New York: IBM Corporation. Recuperado de hftp://ftp.software.ibm.com/la/documents/swg/es/analytics/IBM_Big_Data_Analytics_a umenta_madurez_marketing_digital.pdf

Ivars Baidal, J. A., Solsona Monzonís, F. J., \& Giner Sánchez, D. (2016). Gestión turística y tecnologías de la información y la comunicación (TIC): El nuevo enfoque de los destinos inteligentes. Documents d'Anàlisi Geogràfica, 62(2), 327. Recuperado de https://doi.org/10.5565/rev/dag.285

Kalakota, R.\& Robinson, M. (2001). Del e-commerce al e-business. México: Pearson.

Kinley, T. R., Forney, J. A., \& Kim, Y. (2012). Travel motivation as a determinant of shopping venue. International Journal of Culture, Tourism andHospitalityResearch,6(3),266-278. Recuperado de https://www.emeraldinsight.com/doi/abs/10.1108/17506181211246429

Küster, I., Vila, N., \& Canales, P. (2008). El marketing relacional y el marketing emocional: dos enfoques competitivos para el turismo de sol y playa. Estudiossobreconsumo, 84,31-40. Recuperado dehttps://www.researchgate.net/profile/Ines_Kuester-

Boluda/publication/28243708_El_marketing_relacional_y_el_marketing_emocional_dos_enfoques_competitiv os_para_el_turismo_de_sol_y_playa/links/02bfe51384aa0def49000000/El-marketing-relacional-y-elmarketing-emocional-dos-enfoques-competitivos-para-el-turismo-de-sol-y-playa.pdf

Lara, P. \& Martínez, J. (2002). Comercio electrónico: la fidelización del usuario. Recuperado dewww.uoc.edu/dt/20168/20168.pdf

Laso, I.\& Iglesias, M. (2002). Internet, comercio colaborativo y mcomercio. Madrid: Mundi-Prensa.

Laudon, K. (2014). E-commerce: negocios, tecnología, sociedad. Mexico: Pearson.) Novena Edición.

Martínez, L. (2012). Estrategias de promoción turística .. Recuperado de http://www.scielo.org.co/scielo.php?script=sci_arttext\&pid=S0122-82852012000200006\&lang=pt

Martínez Y., Cachero C., \& Meliá S. (2011). Evidencia empírica sobre mejoras en productividad y calidad en enfoques MDD: un mapeo sistemático. Recuperado de http://www.redalyc.org/pdf/922/92222552003.pdf .

Martínez, J. (2011). Marketing Turisticoon Line, Turydes, Vol. 4, No 9, Escuela Universitaria de Turismo Iriarte, Universidad de La Laguna, España. Recuperado de: http://www.eumed.net/rev/turydes/09/jamg2.pdf

Matellanes, Mónica. (2012). Marketing del enoturismo en la Web 2.0, 75-100. Recuperado de https://dialnet.unirioja.es/descarga/articulo/4080724.pdf

Maurer, C. (2015). Cultural Tourism in a Digital Era, 231-241. Recuperado de https://doi.org/10.1007/978-3-319$15859-4$ 
Mendes Thomaz, Guilherme, Biz, Alexandre Augusto, \& Gândara, José Manoel G. (2013). Innovación en la promoción turística en medios y redes sociales: Un estudio comparativo entre destinos turísticos. Estudios y perspectivas en turismo, 22(1), 102-119. Recuperado de http://www.scielo.org.ar/scielo.php?script=sci_arttext\&pid=S1851$17322013000100006 \& \operatorname{lng}=\mathrm{es} \&$ tlng=es

Metodijeski, D., \& Temelkov, Z. (2014). Tourism Policy of Balkan Countries: Review of National Tourism Development Strategies, 5(2), 231-239. Recuperado de http://www.utmsjoe.mk/files/Vol.\%205\%20No.\%202/2-10_Medodijeski-Temelkov2(1).pdf

Ministerio de Turismo, (2014). Plan Integral de Marketing Turístico. Recuperado de http://www.competencias.gob.ec/wp-content/uploads/2017/06/c.-2014.-PLAN-INTEGRAL-MARKETINGTURISTICO.pdf

Ministerio de Turismo. (2014). Hoy arranca segunda fase de la campaña All You Need Is Ecuador. Recuperado de http://www.turismo.gob.ec/hoy-arranca-segunda-fase-de-la-campana-all-you-need-isecuador/

Miranda, F., Rubio, S., Chamorro, A., \& Correia, S. (2015). Determinantes de la intención de uso de Facebook en el proceso de decisión de compra. Recuperado dehttps://dialnet.unirioja.es/descarga/articulo/4943165.pdf

Moschini, S. (2012). Claves del marketing digital. La nueva comunicación empresarial en el mundo, 3. Recuperado dewww.lavanguardia.com > Cultura > Ebooks de Vanguardia

Nguyen, T. (2017). A chat-based group recomender sistem for tourism. Inf technol tourism. Recuperado de : https://books.google.com.ec/books?id=ty7XDQAAQBAJ\&pg=PA17\&dq=A+chat-

based+group+recommender+system+for+tourism.+Inf+technol+tourism.\&hl=es\&sa=X\&ved=0ahUKEwjY4Iq z3PfbAhVPq1MKHU11ChMQ6AEIKDAA\#v=onepage \&q=A\%20chatbased\%20group\%20recommender\%20system\%20for\%20tourism.\%20Inf\%20technol\%20tourism.\&f=false

Osorio, R., Restrepo, L., \& Muñoz, H. (2016). Marketing digital: Una mirada al pasado, presente y futuro, 3-20. Recuperado de: https://scholar.google.com/citations?user=iLMRfTUAAAAJ\&hl=es\#d=gs_md_cita$\mathrm{d} \& \mathrm{p}=\& \mathrm{u}=\% 2 \mathrm{Fcitations} \% 3$ Fview_op\%3Dview_citation\%26hl\%3Des\%26user\%3DiLMRfTUAAAAJ\%26citati on_for_view\%3DiLMRfTUAAAAJ\%3Au-x6o8ySG0sC\%26tzom\%3D300

Perdomo, L., Rincón, R., Sánchez, M. (2014). Desafíos del marketing turístico en el entorno 2.0. Volumen 2 . No 2. Marketing Visionario. Universidad Privada Dr. Rafael Belloso Chacín. p 125 -141. Recuperado de: http://ojs.urbe.edu/index.php/market/article/view/2356/2182

Pesonen, J. A. (2012). Segmentation of rural tourists: combining push and pull motivations. Tourism and hospitality mangement, 18 (1), 69-82.

Recuperado de: https://hrcak.srce.hr/83824

Petersen, K., Feldt, R., Mujtaba S., and Mattsson, M., (2008). "Systematic MappingStudies in Software engineering," in EASE '08: Proceedings of the 12th International Conference on Evaluation and Assessment in Software Engineering. Recuperado de https://dl.acm.org/citation.cfm?id=2227115.2227123

Rita, P. (2000). Web marketing tourism destinations. Ecis, (2000), 120. Recuperado de: http://citeseerx.ist.psu.edu/viewdoc/download?doi=10.1.1.881.9465\&rep=rep1\&type=pdf

Rodríguez, C. (2009). El marketing de afiliación. REDMARKA - Revista Académica de Marketing Aplicado CIECID - Universidad de A Coruña Año I. Número 1. pp. 151-203. Recuperado de: https://dialnet.unirioja.es/servlet/articulo?codigo $=4128879$

Sambhanthan, A., \& Good, A. (2014). Strategic Advantage in web Tourism Promotion: An e-Commerce Strategy for Developing Countries Strategic Advantage in Web Tourism Promotion: An e-Commerce Strategy for Developing Countries. International Journal of Information Systems in the Service Sector, 6, no.3, 1-21. Recuperado de https://doi.org/10.4018/ijisss.2014070101

Santillán L., Medrano E. (2015). Las redes sociales una alternativa al Marketing en al PYMES. Recuperado de https://dialnet.unirioja.es/servlet/articulo? $\operatorname{codigo}=5833516$

Schegg, R. (2018). Special section on recommendations and analytics in tourism . Inf Technol Tourism (2018) 18:1-4, 18:1-4. Recuperado de https://link.springer.com/article/10.1007/s40558-018-0109-8

Selman, David. (2017). "Marketing digital", Ibukku. Recuperado de https://books.google.es/books?hl=es\&lr=\&id=kR3EDgAAQBAJ\&oi=fnd\&pg=PT10\&dq=Selman,+H.+(2017) .+Markeitng+digital.+IBUKKU\&ots=KHjAKpZYtU\&sig=BnJHSAF4KhX_rD8FGpFdpCs00Nc\#v=onepage $\& q=$ Selman $\% 2 \mathrm{C} \% 20 \mathrm{H} . \% 20(2017) . \% 20$ Markeitng\%20digital.\%20IBUKKU\&f=false

Sellers Rubio, R., Azorín Escolano, A., (2001), "El Comercio electrónico y el futuro del canal de distribución turístico", Investigaciones Europeas de Dirección y Economía de la Empresa, Universidad de Alicante, Vol.7 No 1, pp. 13-36., España Recuperado de: https://dialnet.unirioja.es/descarga/articulo/187785.pdf 
TIC Observatorio, M. d. (28 de enero de 2018). Observatorio TIC. Recuperado de https://observatoriotic.mintel.gob.ec/

Torres, A. (2007). Diseño de una plan de Marketing digital , para posicionar a la agencia de viajes y turismo Emivaltur en la ciudad de Cuenca. Recuperado de http://dspace.uazuay.edu.ec/handle/datos/4529

Turism\&Leisure. (26 de Septiembre de 2007). Diseño del plan estrategico de desarrollo del turismo sostenible para Ecuador "PLANDETUR 2020". Quito, Pichincha, Ecuador. Recuperado de https://books.google.com.ec/books?id=ZnsnAQAAIAAJ

Turism\&Leisure. (1 de agosto de 2009). Plan integral de marketing turístico para el turismo interno de Ecuador. Quito, Pichincha, Ecuador. Recuperado de http://optur.org/pdf/PIMTE_2014-EDICION-Turismo-Interno.pdf

Valerio, I. (jun de 2012). Estrategias de promoción turística.Recuperado de Redalyc.org: http://www.redalyc.org/html/649/64923562006/

Wang, D., Xiang, Z., \& Fesenmaier, D. R. (2016). Smartphone Use in Everyday Life and Travel. Journal of Travel Research, 55(1), 52-63. Recuperado de https://doi.org/10.1177/0047287514535847 